\title{
First report of an outbreak of cerebral coenurosis in Dhofari goats in Oman
}

\author{
Primeiro relato de um surto de coenurose cerebral em cabras Dhofari em Omã \\ Mahmoud Shaban El-Neweshy ${ }^{1,2}$; Reda Elbastawisy Khalafalla ${ }^{2,3 *}$ (D); Mohamed Mohamed Sayed Ahmed ${ }^{4}$; \\ Julanda Hamad Al Mawly²; El-Sayed Mohamed El-Manakhly ${ }^{1,5}$ \\ ${ }^{1}$ Department of Pathology, Faculty of Veterinary Medicine, Alexandria University, Edfina, Behera, Egypt \\ ${ }^{2}$ Central Laboratory for Animal Health, Ministry of Agriculture and Fisheries, Muscat Sultanate of Oman \\ ${ }^{3}$ Department of Parasitology, Faculty of Veterinary Medicine, Kafrelsheikh University, Kafr El-Sheikh, Egypt \\ ${ }^{4}$ Department of Pathology, Faculty of Veterinary Medicine, Kafrelsheikh University, Kafr El-Sheikh, Egypt \\ ${ }^{5}$ Department of Veterinary Medicine, College of Agriculture and Veterinary Medicine, Qassim University, Buraydah, Saudi Arabia
}

Received April 21, 2019

Accepted June 3, 2019

\begin{abstract}
This study documented the first outbreak of cerebral coenurosis in goats in Salalah, southern Oman. Deaths of 130 (16.6\%) adult native goats in a herd $(\mathrm{n}=780)$ were reported from January to June 2017. Affected goats showed various nervous signs ended by death. Investigations for thiamine deficiency, polioencephalomalacia, caprine arthritis encephalitis, and listeriosis were negative. Upon necropsy, multiple (1-4) thin-walled cysts $2-3.5 \mathrm{~cm}$ in diameter containing clear fluid with numerous clusters of protoscolices in the cerebrum and cerebellum had replaced the brain parenchyma, causing space-occupying lesions. Parasitologically, the recovered cysts were Coenurus cerebralis, based on the arrangement of protoscolices, and the number and size of their hooks. Morphologically, each protoscolex had four suckers and a rostellum with double-crown hooks. The large and small hooks were $157.7 \pm 0.5 \mu \mathrm{m}$ and $115 \pm 0.6 \mu \mathrm{m}$ in length, respectively. Histopathologically, the parasite destroyed the affected tissues associated with multifocal to diffuse lymphocytic, non-suppurative meningoencephalitis; ischemic neuronal necrosis; and malacia. This is the first report of cerebral coenurosis in livestock in Oman, which should alert the local public health authorities for the application of prevention and control measures.
\end{abstract}

Keywords: Cerebral, coenurosis, Coenurus cerebralis, goats, histopathology, Oman.

\section{Resumo}

Este estudo documentou o primeiro surto de coenurose cerebral em cabras em Salalah, Oman. A morte de 130 (16,6\%) caprinos adultos nativos $(\mathrm{n}=780)$ foi relatada de janeiro a junho de 2017. As cabras afetadas mostraram distúrbios neurológicos, que culminaram em óbito. Investigaçóes para deficiência de tiamina, polioencefalomalácia, encefalite por artrite caprina e listeriose foram negativas. Na necropsia, múltiplos (1-4) cistos de paredes finas com 2-3,5 cm de diâmetro contendo líquido claro com numerosos aglomerados de protoescólices no cérebro e no cerebelo haviam substituído o parênquima cerebral, causando compressão nas estruturas adjacentes. Os cistos recuperados foram identificados como sendo de Coenurus cerebralis, com base no arranjo dos protoescólices, e no número e tamanho de seus ganchos. Morfologicamente, cada protoescólice

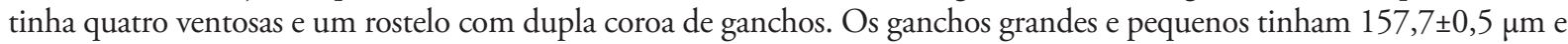
$115 \pm 0,6 \mu \mathrm{m}$ de comprimento, respectivamente. Histopatologicamente, o parasita causou a destruiçáo dos tecidos afetados associada à meningoencefalite linfocítica não-supurativa, que variou de multifocal a difusa, necrose neuronal isquêmica e malacia. Este é o primeiro relato de coenurose em ruminantes no Oman, o que deve servir de alerta para as autoridades locais da área de saúde para a aplicação de medidas de prevenção e controle.

Palavras-chave: Paralisia, coenurosis, Coenurus cerebralis, cabras, histopatologia, Oman.

\section{Introduction}

Coenurosis is a parasitic disease of a great economic impact on various livestock worldwide, particularly small ruminants. Coenurus cerebralis, the larval stage of Taenia multiceps (Leske 1780, syn.

${ }^{*}$ Corresponding author: Reda EL-Bastawisy Khalafalla. Department of Parasitology, Faculty of Veterinary Medicine, Kafrelsheikh University, P.O. Box 33516, Kafr El-Sheikh, Egypt. E-mail: redabast@hotmail.de
Multiceps multiceps), causes coenurosis. Taenia multiceps is a taeniid cestode; its adult stage inhabits the small intestine of domestic and wild canids, the final host. Final hosts become infected with T. multiceps by eating animal tissues containing the larval stage and then dispatch eggs in their feces. Intermediate hosts become infected by ingestion of eggs in food and water contaminated with 
infected canid feces. The larval stages migrate through the blood and lymphatic system to reach the predilection sites, the brain and spinal cord, where it develops into a cyst within 2-3 weeks (SOULSBY, 1982).

Cerebral coenurosis refers to the occurrence of $C$. cerebralis in the brain and spinal cord, is common in a wide range of livestock, particularly sheep and goats but rarely reported in cattle (GIADINIS et al., 2007, 2009). Cerebral coenurosis is mostly associated with neurological disorders (ORYAN et al., 2015; SHARMA \& CHAUHAN, 2006). The severity of the disease depends on the location and the space occupied by the cyst, and the associated neuropathological lesions (ACHENEF et al., 1999; SHIVASHARANAPPA et al., 2017). Whereas non-cerebral coenurosis, caused by Taenia giageri, is frequently reported in musculature of sheep and goats (CHRISTODOULOPOULOS et al., 2013, 2015; EL SINNARY et al., 1999; SAMI et al., 2014; SCHUSTER et al., 2010).

Clinically, cerebral coenurosis is reported in either acute or chronic form. The acute form occurs due to intense larval migration in the central nervous system (CNS) following the exposure to massive parasitic infestation, while the chronic form is frequently recorded as bladder cysts development in the CNS (ABERA et al., 2016; ORYAN et al., 2014). Chronic cerebral coenurosis is more common than the acute form, and both forms are fatal (ALEMU et al., 2015).

Several human cases of cerebral coenurosis have been reported (AMBEKAR et al., 2013; ANTONIOS \& MINA, 2000; COLLOMB et al., 2007; HAITCHI et al., 2012; SCHELLHAS \& NORRIS, 1985) due to consumption of contaminated foods with T. multiceps eggs and develop the same pathogenesis as described in other intermediate hosts (ACHA \& SZYFRES, 2003).

Sheep and goats are important for the economy of Oman, and represent up to $70 \%$ and $18 \%$, respectively, of the total livestock population (MASCATE, 2013).

Recently, high rates of goat mortalities with a history of neurological signs were noticed in a goat herd in the Salalah region, southern Oman. We aimed to investigate the potential role of $C$. cerebralis in such goat mortalities.

\section{Materials and Methods}

\section{Case history}

High mortalities have been reported over a period of 6 months (January-June 2017) in Dhofari goat herd in Salalah (Capital of Dhofar province, southern Oman). Out of 780, 130 (16.6\%) adult goats died with history of nervous signs. Animals were treated for thiamine deficiency, Oestrus ovis, and blood parasites, but the mortalities persisted.

\section{Necropsy}

Fifteen alive sick goats were sent to the Central Laboratory for Animal Health (Ministry of Agriculture and Fisheries, Oman) during illness to investigate the cause of mortalities. Physical and clinical examinations were applied before slaughtering.
Slaughtered animals were inspected for any abnormalities. A special attention was paid for the brains and spinal cords for the presence of cysts, tumors, or any other apparent lesions that may cause the nervous manifestations. All brains were examined with ultraviolet light illumination for polioencephalomalacia.

\section{Histopathology}

Specimens from brain, spinal cord, liver, lung, kidneys, heart, and intestine were collected and fixed in $10 \%$ buffered formalin for histopathological examination. The fixed specimens were processed for paraffin-embedded sections, which stained with hematoxylin and eosin (H\&E), Culling (1974). Paraffin-embedded brain sections were stained with Gram (ENGBAEK et al., 1979) and Ziehl-Neelsen stains (VAN DER ZANDEN et al., 1998).

\section{Parasitological examination}

The collected brain cysts were washed in phosphate buffered saline and all morphological features were documented. Protoscolices of each cyst were preserved in $70 \%$ ethanol. Thereafter, they were mounted in a solution composed of lactophenol, formaldehyde, and absolute ethanol (KENNEDY, 1979). To flatten the scolices, sufficient pressure was achieved using a cover-slip. Numbers and sizes of the small and large hooks of each scolex were counted and measured to identify the cyst (ORYAN et al., 2015).

\section{Other laboratory investigations}

A real-time PCR for Listeria monocytogenes (BioRad, Hercules, CA, USA) was applied on pooled brain samples collected from the slaughtered goats.

One hundred serum samples were randomly collected from the goat herd along with the fifteen serum samples of slaughtered animals. All serum samples were screened for caprine arthritis encephalitis (CAE) virus antibodies by ID Screen ELISA (ID.VET Innovative Diagnostics, Grabels, France).

\section{Results}

\section{Clinical signs}

Diseased goats exhibited the following symptoms: depression, ataxia, head tilt, star gazing, a tendency to keep away from other animals in the flock, neck rigidity, irregular gait, circling movement, head pressing against a wall, lateral recumbency with stretched limbs, and convulsions, followed by death (Figure 1, Table 1). Other than those clinical manifestations, no abnormal clinical signs were observed.

\section{Postmortem findings}

Postmortem examination revealed no prominent pathological findings in the internal organs. Dissection of their craniums showed the presence of 1-4 white thin-walled unilocular cysts 


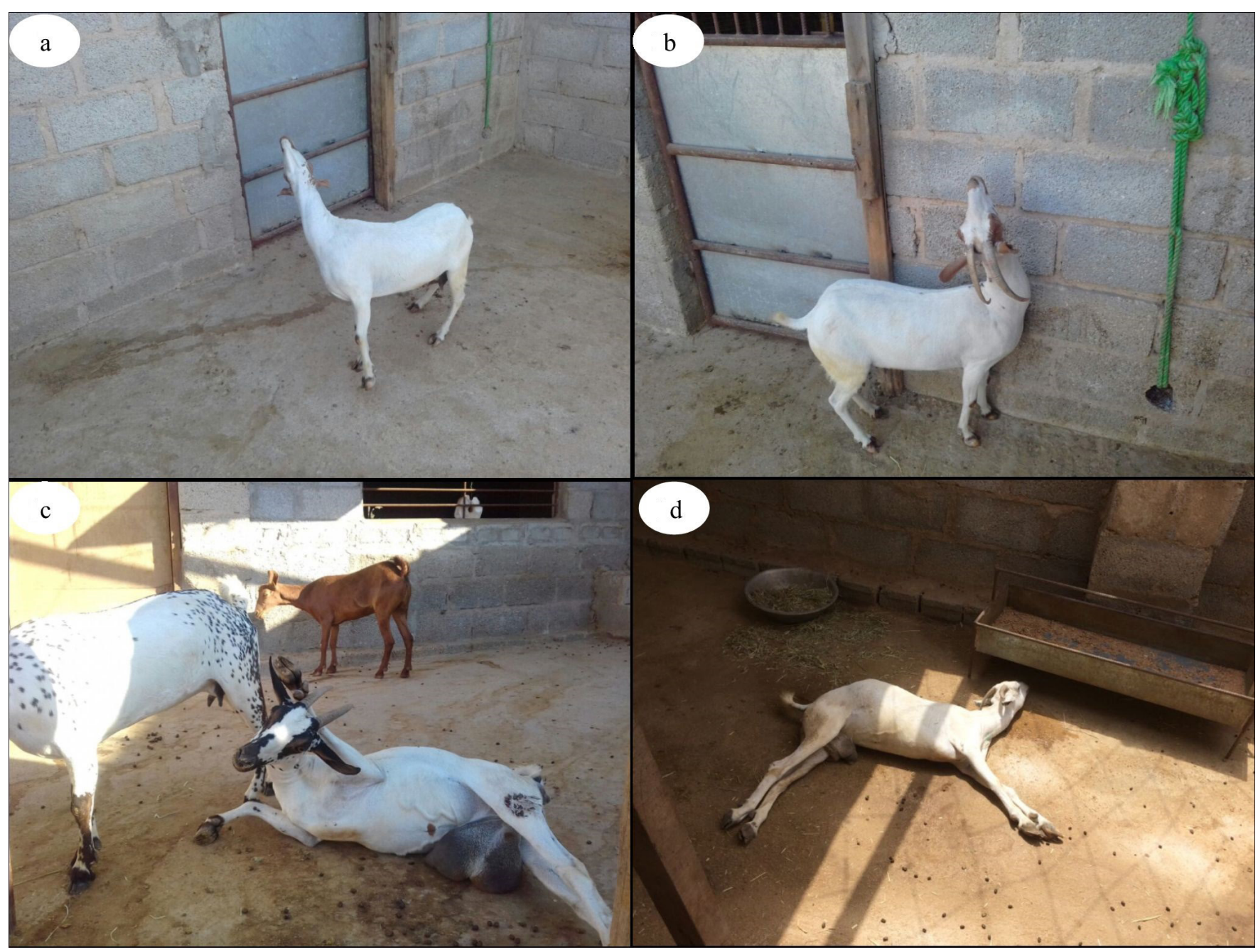

Figure 1. Some clinical signs of cerebral coenurosis in Dhofari goats: neck rigidity (a), star gazing (b), head deviation (c), and recumbency with extended neck, limbs, and tail (d).

Table 1. Details of the history, clinical signs, and postmortem findings of 15 necropsied Dhofari goats infested with $C$. cerebralis.

\begin{tabular}{|c|c|c|c|c|c|c|c|c|c|c|c|c|c|c|c|c|}
\hline \multirow[b]{2}{*}{ Parameters } & & \multicolumn{15}{|c|}{ Animals } \\
\hline & & 1 & 2 & 3 & 4 & 5 & 6 & 7 & 8 & 9 & 10 & 11 & 12 & 13 & 14 & 15 \\
\hline & Sex & $\mathrm{F}$ & $\mathrm{F}$ & $\mathrm{F}$ & $\mathrm{F}$ & M & $\mathrm{F}$ & $\mathrm{F}$ & $\mathrm{F}$ & $\mathrm{F}$ & $\mathrm{F}$ & M & $\mathrm{F}$ & $\mathrm{F}$ & $\mathrm{F}$ & $\mathrm{F}$ \\
\hline & Age & $1 \mathrm{Y}$ & $2.5 \mathrm{Y}$ & $2 \mathrm{Y}$ & $1 \mathrm{Y}$ & $1.5 \mathrm{Y}$ & $3 \mathrm{Y}$ & $3 \mathrm{Y}$ & $2 Y$ & $1.5 \mathrm{Y}$ & $1 \mathrm{Y}$ & $2 \mathrm{Y}$ & $1 \mathrm{Y}$ & $2.5 \mathrm{Y}$ & $3 \mathrm{Y}$ & $2.5 \mathrm{Y}$ \\
\hline \multirow{12}{*}{$\begin{array}{l}\text { Clinical } \\
\text { signs }\end{array}$} & Circling & & & & & & & & & & & & & & & \\
\hline & Clockwise circling & - & + & - & - & + & + & + & - & + & + & - & - & - & - & - \\
\hline & Anticlockwise circling & - & - & - & - & + & - & - & - & - & + & + & - & + & + & + \\
\hline & Head position & & & & & & & & & & & & & & & \\
\hline & Right head tilt & + & + & - & - & - & + & - & - & + & - & - & - & - & - & - \\
\hline & Left head tilt & - & - & + & + & + & - & - & - & - & + & + & + & - & + & + \\
\hline & Star gazing & + & + & - & - & - & + & - & - & - & + & + & - & + & + & - \\
\hline & Lowered head & - & - & - & + & - & - & - & + & - & - & - & + & - & - & - \\
\hline & Pressing head against wall & - & - & - & - & + & - & + & - & - & - & - & - & + & - & - \\
\hline & Irregular gait & + & + & + & + & + & + & + & + & + & + & + & + & + & + & + \\
\hline & Ataxia & + & + & + & + & + & + & + & + & + & + & + & + & + & + & + \\
\hline & Recumbency & + & + & - & + & - & - & + & + & + & + & - & - & + & + & - \\
\hline
\end{tabular}


Table 1. Continued..

\begin{tabular}{|c|c|c|c|c|c|c|c|c|c|c|c|c|c|c|c|c|}
\hline & & \multicolumn{15}{|c|}{ Animals } \\
\hline \multirow[t]{12}{*}{$\begin{array}{l}\text { Postmortem } \\
\text { findings }\end{array}$} & \multicolumn{16}{|l|}{$\begin{array}{l}\text { Cysts location/ Number/ } \\
\text { cyst diameter (cm) }\end{array}$} \\
\hline & \multicolumn{16}{|l|}{ Right cerebral hemisphere } \\
\hline & Parietal Lobe & One & Two & One & - & - & One & - & - & One & Two & - & - & - & - & - \\
\hline & & 3.4 & $\begin{array}{l}2.0 \\
2.2\end{array}$ & 3.5 & & & 3.1 & & & 3.4 & $\begin{array}{l}2.7 \\
2.5\end{array}$ & & & & & \\
\hline & Occipital Lobe & - & - & - & $\begin{array}{l}\text { One } \\
2.3\end{array}$ & - & - & - & - & - & - & - & $\begin{array}{l}\text { One } \\
3.0\end{array}$ & - & - & - \\
\hline & Frontal Lobe & - & - & - & - & - & - & $\begin{array}{l}\text { One } \\
2.9\end{array}$ & - & - & - & - & - & - & - & - \\
\hline & \multicolumn{16}{|l|}{ Left cerebral hemisphere } \\
\hline & Parietal Lobe & - & - & - & - & $\begin{array}{l}\text { One } \\
2.6\end{array}$ & - & - & - & - & $\begin{array}{l}\text { One } \\
3.1\end{array}$ & $\begin{array}{l}\text { One } \\
3.4\end{array}$ & - & $\begin{array}{l}\text { One } \\
2.9\end{array}$ & $\begin{array}{l}\text { One } \\
3.2\end{array}$ & $\begin{array}{l}\text { One } \\
2.8\end{array}$ \\
\hline & Occipital Lobe & - & - & - & - & - & - & - & - & - & - & - & - & - & - & - \\
\hline & Frontal Lobe & - & - & - & - & $\begin{array}{l}\text { One } \\
2.2\end{array}$ & - & - & - & - & $\begin{array}{l}\text { One } \\
2.1\end{array}$ & - & - & $\begin{array}{l}\text { One } \\
2.1\end{array}$ & - & - \\
\hline & $\begin{array}{l}\text { Cerebral hemisphere } \\
\text { median fissure }\end{array}$ & $\begin{array}{l}\text { One } \\
2.5\end{array}$ & - & - & - & - & - & - & - & - & - & - & - & - & - & - \\
\hline & Cerebellum & - & - & $\begin{array}{l}\text { One } \\
2.4\end{array}$ & - & - & - & - & $\begin{array}{l}\text { One } \\
2.8\end{array}$ & - & - & - & - & - & - & - \\
\hline
\end{tabular}

F: Female M: Male.

of variable sizes in their cerebral hemispheres $(n=14)$, to a lesser extent in the cerebellum $(n=2)$, and occasionally in the cerebral median fissure $(n=1)$. Neither cysts nor lesions were seen elsewhere, even in the spinal cord or skeletal muscles. Cerebral cysts were resided underneath the superficial layer of the cerebral hemispheres, leaving deep compartments with pressure atrophy of the adjacent gray and white matter (Figures $2 \mathrm{a}$ and $2 \mathrm{~b}$ ). However, the cerebellar cysts were superficially found in the subarachnoid space. Locations, numbers, and sizes of brain cysts are summarized in Table 1.

\section{Parasitological findings}

The recovered cysts were nearly spherical in shape; they were unilocular bladders filled with clear fluid $-2-3.5 \mathrm{~cm}$ in diameter. Neither external nor internal daughter cysts were observed. The wall of the cysts was a semitransparent membrane with a surface studded with aggregates of minute, white granules, namely protoscolices (Figure 2b, inset). Protoscolices were 300-400 per cyst and each protoscolex had 4 suckers and a rostellum (Figure 2c). The rostellum was armed with 26-28 large and small hooks, each in a row. The large hooks had a notch on their handles (Figure $2 \mathrm{~d}$ ). The length (tip to tip) was 150-166 $\mu \mathrm{m}$ (mean: $157.7 \pm 0.5 \mu \mathrm{m}$ ) and $105-120 \mu \mathrm{m}$ (mean: $115 \pm 0.6 \mu \mathrm{m}$ ) for the large and small hooks, respectively. Also, the length of the handle, guard, and blade was measured (Table 2).

\section{Histomorphology of C. cerebralis and neuropathological findings}

Histomorphologically, cysts were unilocular and loosely attached to the underside of the inflamed brain tissue, with eosinophilic hyaline bonds and studded with many invaginated protoscolices. Structures of each protoscolex are shown in Figure 3. The cyst wall was three-layered; an external layer covered by basophilic microtriches, a middle cellular layer, and an inner, homogenous, areolar germinal membrane. Numerous mononuclear cells infiltrated the wall of the degenerating cysts and, in some cases, neutrophils were diffusely seen in the lumina of the degenerating cysts. Some cysts were surrounded by granulomatous inflammation; the majority of inflammatory cells were macrophages, lymphocytes, and few plasma and epithelioid cells, as well as foreign-body giant cells (Figure 4a). The inflammatory reaction also extended into the adjacent brain and cerebellar tissues in the form of mild non-suppurative meningoencephalitis (Figures $4 \mathrm{~b}$ and $4 \mathrm{c}$ ). Satellitosis, perivascular cuffing, and focal mineralization were seen near the margins of the cysts. There was an accumulation of hemosiderin-containing gitter cells near the margins of the cyst and within the cavity.

Affected brain tissues showed axonal dystrophy in the form of focal axonal swelling with the formation of a homogenous hyaline mass (spheroid) (Figure 4d), while liquefactive necrosis of the brain tissue (malacia) revealed a cavity filled with necrotic brain tissue debris with extensive inflammatory cell infiltration of foamy macrophages, accompanied by neovascularization 


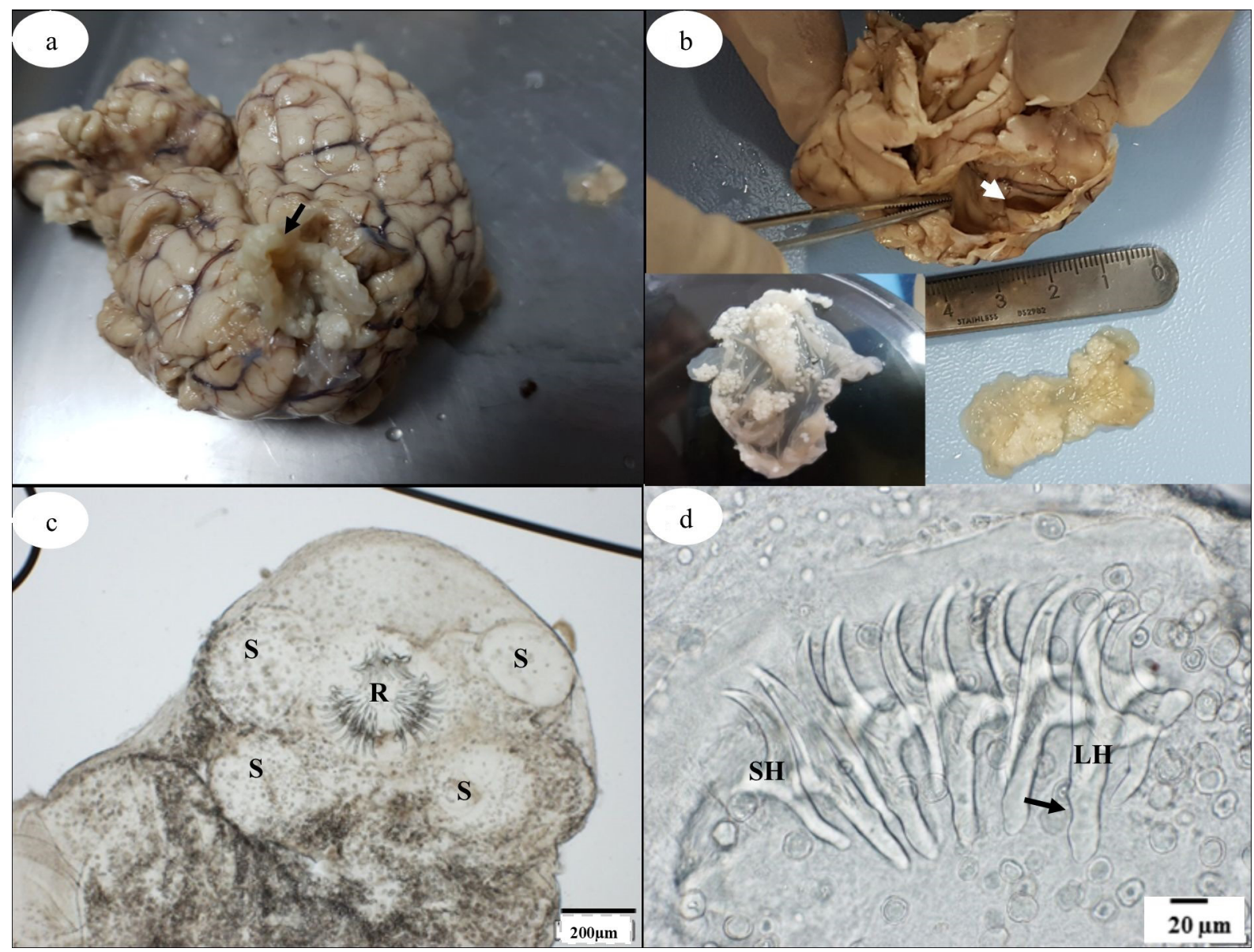

Figure 2. The location of C. cerebralis in the brain of an adult Dhofari goat and its gross and microscopical morphology of the cyst and protoscolices; respectively. C. cerebralis (arrow) is located underneath the surface of the parietal lobe in the right cerebral hemisphere (a), leaving a deep compartment (white arrow) with pressure atrophy of the cerebral cortex (b). Figure (2b, inset) shows the collapsed unilocular cyst, which is composed of a semitransparent wall studded with many small white protoscolices. (c) Microscopically, the fresh, unstained protoscolex has 4 suckers (S), and the rostellum (R) armed with double-crowned taeniid hooks, long hooks (LH), and short hooks (SH). (d) shows how the handle of the SH are turned dorsally, while the handle of the LH has a dorsal notch (black arrow) and is slightly curved backward at the distal extremity.

Table 2. Morphometric measurements of the rostellar hooks of C. cerebralis recovered from the brain of a Dhofari goat.

\begin{tabular}{|c|c|c|c|c|c|c|c|c|c|c|c|}
\hline & \multirow[b]{2}{*}{$\begin{array}{c}\text { Total } \\
\text { number } \\
\text { of hooks }\end{array}$} & \multicolumn{5}{|c|}{ measurements of large hooks $(\mu \mathrm{m})(\mathrm{n}=280)$} & \multicolumn{5}{|c|}{ measurements of small hooks $(\mu \mathrm{m})(\mathrm{n}=275)$} \\
\hline & & number & $\begin{array}{c}\text { Total } \\
\text { length of } \\
\text { hook }\end{array}$ & $\begin{array}{l}\text { Length of } \\
\text { blade }\end{array}$ & $\begin{array}{l}\text { Length of } \\
\text { handle }\end{array}$ & $\begin{array}{l}\text { length of } \\
\text { guard }\end{array}$ & number & $\begin{array}{c}\text { Total } \\
\text { length of } \\
\text { hook }\end{array}$ & $\begin{array}{l}\text { Length of } \\
\text { blade }\end{array}$ & $\begin{array}{l}\text { Length of } \\
\text { handle }\end{array}$ & $\begin{array}{l}\text { length of } \\
\text { guard }\end{array}$ \\
\hline Average & 27.8 & 14 & 157.7 & 74.8 & 88.1 & 52.2 & 13.8 & 115.0 & 56.8 & 66.5 & 43.2 \\
\hline $\begin{array}{l}\text { Range } \\
(\max -\min )\end{array}$ & $26-28$ & $15-13$ & $166-150$ & $88-65$ & $99-74$ & $67-40$ & $12-14$ & $124-105$ & $67-51$ & $77-54$ & $52-33$ \\
\hline SEM & 0.1 & 0.1 & 0.5 & 0.7 & 0.9 & 1.1 & 0.1 & 0.6 & 0.5 & 0.9 & 0.6 \\
\hline
\end{tabular}

and fibroblast cell proliferation (Figure 4e). Further, ischemic neuronal injury with pyknotic nuclei and presence of gitter cells (foamy macrophages), microgliosis (perineuronal satellitosis), and cerebral hemorrhage was observed, in which red blood cells scattered in the parenchyma of the brain outside the blood vessels (Figure 4f). Moderate to severe infiltration of the inflammatory cells, mainly lymphocytes and macrophages, were seen in the cerebellar cortex underneath the meningeal membranes. No bacteria was detected in Gram and Ziehl-Neelsen stained brain sections.

\section{Listeria monocytogens and CAE virus detection}

Results of PCR detection of Listeria monocytogenes in the brain tissues, as well as ELISA detection of CAE virus antibodies in sera of the examined goats were negative. 


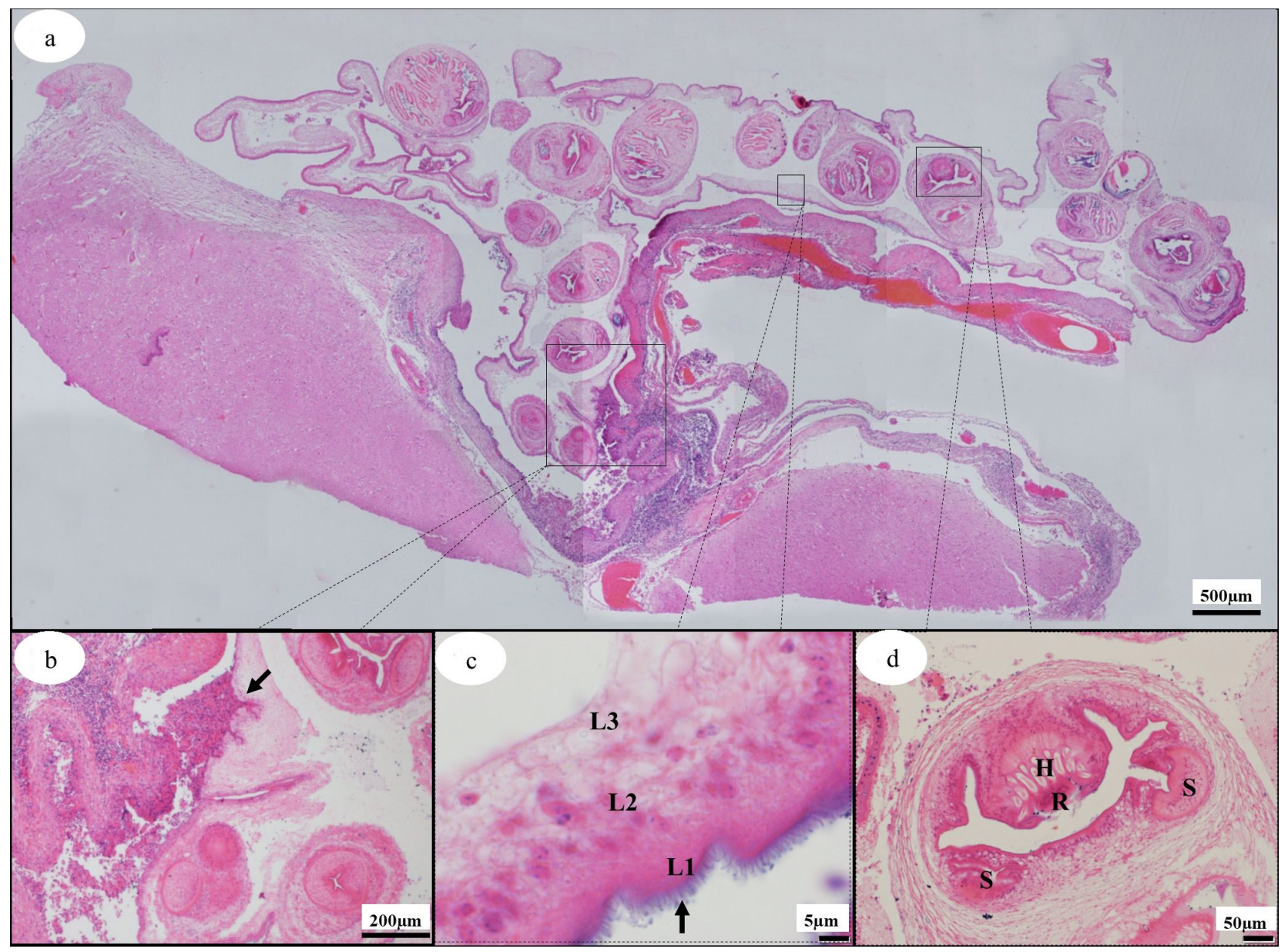

Figure 3. Histomorphology of C. cerebralis located in the subarachnoid space of an adult Dhofari goat brain stained with H\&E: unilocular cyst studded with protoscolices of different sizes (a); the cyst is loosely attached underneath the severely inflamed meninges (arrow), with a few hyaline bonds (b). (c) the cyst wall composed of a three-layered structure: an external layer (L1) covered by microtriches (arrow), a middle cellular layer (L2), and d an inner homogenous, areolar, germinal membrane (L3) studded with invaginated protoscolices (3) with suckers (S) and the rostellum $(\mathrm{R})$ lined with double rows of refractile hooks $(\mathrm{H})$.

\section{Discussion}

Cerebral coenurosis is a serious disease of small ruminants (ING et al., 1998; LESCANO \& ZUNT, 2013). A single report documented a fatal case of extra-cerebral coenurosis caused by Taenia giageri in an Anglonubian goat farm in the Sultanate of Oman (EL SINNARY et al., 1999). Cysts were abundant in the muscles, while there were fewer in the pancreas, adrenal glands, and parotid salivary gland, but the authors did not find any in the CNS.

Cerebral coenurosis is endemic in Middle Eastern countries, with many reports originating from Iran (KHEIRANDISH et al., 2012; MOGHADDAR, 2007; TAVASSOLI et al., 2011), Egypt (ABBAS \& ELBESKAWY, 2016; AMER et al., 2017), Turkey (AVCIOGLU et al., 2011; GAZIOGLU et al., 2017; GICIK et al., 2007), Jordan (ABO-SHEHADA et al., 2002) and Iraq (KARIM, 1979).

Infection spread seems to be ecology-dependent, aggravated by rainfall, high moisture, and moderate temperature of the altitudes, which keep the parasitic eggs viable for longer periods and facilitates their dispersion over distant regions (ABERA et al., 2016; SCALA \& VARCASIA, 2006). Salalah region has humid weather from June to September (KWARTENG et al., 2009). The affected goats were grazing on Salalah mountains following rainy season, wherein dogs and other wild canids are roaming. Many factors could keep the parasite life cycle in such opened grazing areas such as poor management, unhygienic disposal of dead animals, no guard dogs deworming, and exposure to stray dogs and wild canids.

Clinical cerebral coenurosis occurs in small ruminants and sheep are mostly susceptible (ABERA et al., 2016; SHARMA \& CHAUHAN, 2006). In the present study, the problem was investigated in a goat farm. Affected goats exhibited non-specific nervous system manifestations. Other causes of nervous sign were excluded such as thiamine deficiency, polioencephalomalacia, CAE and listeriosis. The current recorded nervous signs were similar to those recorded in naturally or experimentally infected caprine cases with cerebral coenurosis (NOURANI \& KHEIRABADI, 


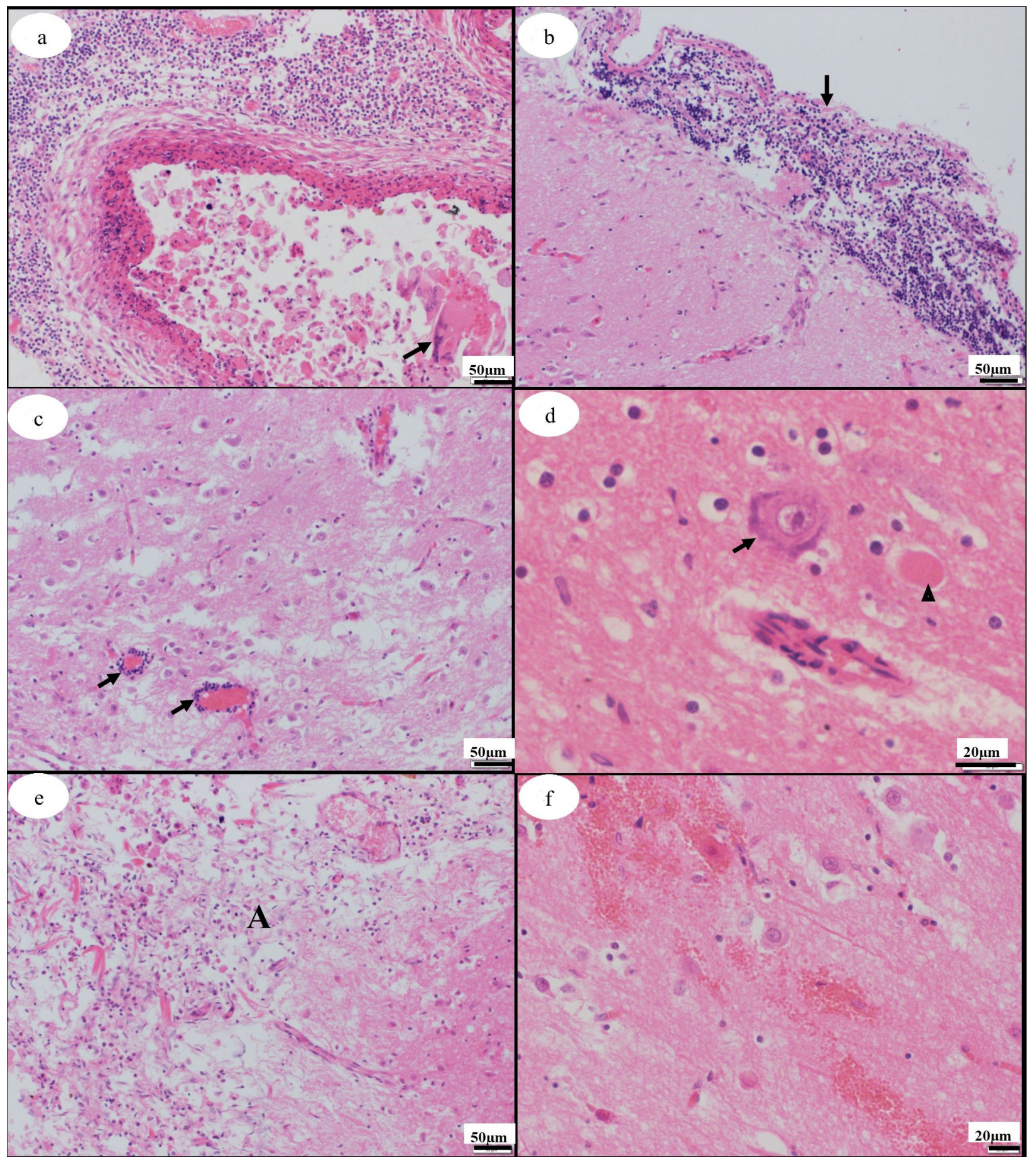

Figure 4. Neuropathological lesions in the brain of Dhofari goats infested with C. cerebralis stained with H\&E: (a) A granulomatous inflammatory reaction surrounding a degenerated cyst; the majority of inflammatory cells present were macrophages, lymphocytes, a few plasma and epithelioid cells, as well as foreign-body giant cells (arrow). (b) Severe lymphocytic meningitis (arrow), (c) perivascular lymphocytic cuffing (arrows), (d) neuronal tigrolysis (arrow) with focal axonal swelling featuring formation of a homogenous hyaline mass (arrow head), (e) malacia and gitter cell proliferation with neovascularization and fibroblast cell proliferation (A), and (f) cerebral hemorrhages.

2009; ORYAN et al., 2015; POLIZOPOULOU et al., 2016; SHIVASHARANAPPA et al., 2017).

C. cerebralis acts as a space-occupying lesion, and its resulting clinical signs are discrete and mostly related to its size and location in the CNS. In the current study, the affected goats had an affinity to circle and head tilt toward the side of brain cyst. Further, some goats demonstrated specific behaviors, such as star gazing, lowering of the head, or pressing their heads against a wall; these goats had at least one cyst in the lateral, occipital, or frontal lobe of the cerebrum, respectively. Also, intermittent clockwise and 
anticlockwise circling was noticed in goats with at least one cyst in each cerebral hemisphere (Table 1). These results are nearly similar to the findings of cerebral coenurosis in sheep (EDWARDS \& HERBERT, 1982; GAZIOGLU et al., 2017).

In the present study, cranial dissection of the affected animals revealed the presence of white, thin-walled cysts of variable sizes in the subarachnoid space of the cerebral hemisphere (93.3\%) and, to a lesser extent, in the median fissure between cerebral hemispheres (6.6\%) and in the cerebellum (13.3\%), which evoked severe pressure atrophy of the cerebral and cerebellar tissues (Table 1).

Similar findings were reported cerebral hemispheres in 88-96.7\% of examined animals (ACHENEF et al., 1999; DERESSA et al., 2012; GICIK et al., 2007; NOURANI \& KHEIRABADI, 2009; TAVASSOLI et al., 2011). Epstein et al. (1959) suggested the development of $C$. cerebralis cysts through the CSF pathway. Most of the reported cysts in sheep are related to the subarachnoid space, which facilitate the nourishment of cysts via the CSF (SCALA \& VARCASIA, 2006).

In this study, number and sizes of the recovered cysts are similar to those reported in literature (GICIK et al., 2007; TAVASSOLI et al., 2011). Morphologically, the recovered cysts possessed $\sim$ 300-400 protoscolices per cyst which coincide with results of other studies (MICHAL et al., 1977; RAZIG \& MAGZOUB, 1973; TIRGARI et al., 1987). Difference in protoscolex numbers may be associated with the degree of cysts maturity. The number of rostellar hooks (26-28) observed in the current study is, consistent with previously reported data published for both adults and larval stages of T. multiceps (LOOS-FRANK, 2000; OGE et al., 2012; VERSTER, 1969).

The lengths of the large and small hooks were $157.7 \pm 0.5 \mu \mathrm{m}$ $(150-166 \mu \mathrm{m})$ and $115 \pm 0.6 \mu \mathrm{m}(105-124 \mu \mathrm{m})$, respectively (Table 2). These morphometric characteristics are comparable to those of the previous literatures (CLAPHAM \& PETERS, 1941; LOOS-FRANK, 2000; OGE et al., 2012; ORYAN et al., 2014; ROSTAMI et al., 2013; VERSTER, 1969).

Pathological alterations of the affected brain tissues in the present study are somewhat extensive than the focal granulomatous reactions reported by Kheirandish et al. (2012), Nourani \& Kheirabadi (2009) and Shivasharanappa et al. (2017). This variation of cyst-induced inflammatory reaction may be attributed to the host immune status and parasitic burden.

Moreover, the obtained cysts were invaded and surrounded by inflammatory cells with few plasma and epithelioid cells. Also, severe lymphocytic meningitis and perivascular lymphocytic cuffing were evident. Changes in the meningeal membranes were secondary to the occurrence of cysts inside the subarachnoid space. Coenurus cerebralis cysts had no vascularity and were surrounded by a thick, three-layered wall that possessed a large number of protoscolices attached to the wall (HARIDY et al., 2013). Additionally, the observed malacic lesions could be due to the migratory tracks of C. cerebralis larvae in the brain parenchyma and this assumption matches the description made by Cantile \& Youssef (2015).

When $C$. cerebralis was located in the CNS, resulting in space-occupying lesions, the mortality rate reached 100\% (AHMED \& ALI, 1972, cited in SHARMA \& CHAUHAN, 2006). Chemotherapy is ineffective and the surgical intervention is only recommended for valued animals (SHARMA \& CHAUHAN, 2006).
In conclusion, the current study documents the first occurrence of cerebral coenurosis in goats from Oman based on clinical signs, postmortem, parasitological and histopathological findings. The local public health authorities were informed to apply suitable preventive and control measures. Further molecular and epidemiological studies on coenurosis are needed in Sultanate of Oman.

\section{Acknowledgements}

This research did not receive any specific grants from funding agencies in the public, commercial, or not-for-profit sectors. All members of the local directorate of Dhofar and the Central Laboratory for Animal Health, Directorate General of Animal Wealth, Ministry of Agriculture and Fisheries, Sultanate of Oman are sincerely thanked by the authors for their valuable help and support.

\section{References}

Abbas I, Elbeskawy M. Molecular and phylogenetic status of Coenurus cerebralis infecting sheep from Dakahlia province, Egypt. J Adv Parasitol 2016; 3(4): 117-124. http://dx.doi.org/10.14737/journal.jap/2016/3.4.117.124

Abera S, Wubit T, Nejash A. Cerebral coenurosis in small ruminants: a review. JAnim Sci Adv 2016; 6(3): 1595-1608. http://dx.doi.org/10.5455/ jasa.20160409121545.

Abo-Shehada MN, Jebreen E, Arab B, Mukbel R, Torgerson PR. Prevalence of Taenia multiceps in sheep in northern Jordan. Prev Vet Med 2002; 55(3): 201-207. http://dx.doi.org/10.1016/S0167-5877(02)00056-9. PMid:12383656.

Acha PN, Szyfres B. Zoonoses and communicable diseases common to man and animals. 3rd ed. Washington: Pan American Health Org; 2003. (Scientific and Technical Publication, No. 580),

Achenef M, Markos T, Feseha G, Hibret A, Tembely S. Coenurus cerebralis infection in Ethiopian highland sheep: incidence and observations on pathogenesis and clinical signs. Trop Anim Health Prod 1999; 31(1): 15-24. http://dx.doi.org/10.1023/A:1005125316275. PMid:10399813.

Alemu S, Kemal J, Muktar Y, Terefe G. Immunological and molecular diagnostic tests for cestodes and metacestodes. World Appl Sci J 2015; 33(12): 1867-1879

Ambekar S, Prasad C, Dwarakanath S, Mahadevan A. MRS findings in cerebral coenurosis due to Taenia multiceps. J Neuroimaging 2013; 23(1): 149-151. http://dx.doi.org/10.1111/j.1552-6569.2011.00616.x. PMid:21699611.

Amer S, ElKhatam A, Fukuda Y, Bakr LI, Zidan S, Elsify A, et al. Prevalence and Identity of Taenia multiceps cysts "Coenurus cerebralis" in Sheep in Egypt. Acta Trop 2017; 176: 270-276. http://dx.doi.org/10.1016/j. actatropica.2017.08.012. PMid:28823911.

Antonios S, Mina S. A case report of human coenurus cerebralis in Tanta, Egypt. J Egypt Soc Parasitol 2000; 30(3): 959-960. PMid:11198393.

Avcioglu H, Yildirim A, Duzlu O, Inci A, Terim KK, Balkaya I. Prevalence and molecular characterization of bovine coenurosis from Eastern Anatolian region of Turkey. Vet Parasitol 2011; 176(1): 59-64. http:// dx.doi.org/10.1016/j.vetpar.2010.10.033. PMid:21074326. 
Cantile C, Youssef S. Nervous system. In: Maxie G. Jubb, Kennedy \& Palmer's pathology of domestic animals (6th ed.). USA: Saunders Ltd.; 2015. Vol. 1, p. 250-406.

Christodoulopoulos G, Kassab A, Theodoropoulos G. Occurrence of non-cerebral coenurosis in sheep. J Helminthol 2013; 87(1): 125-127. http://dx.doi.org/10.1017/S0022149X1100085X. PMid:22260813.

Christodoulopoulos G, Kassab A, Theodoropoulos G. Characteristics of non-cerebral coenurosis in tropical goats. Vet Parasitol 2015; 211(3-4): 216-222. http://dx.doi.org/10.1016/j.vetpar.2015.05.020. PMid:26073108.

Clapham P, Peters B. The differentiation of Coenurus species by hook measurements. J Helminthol 1941; 19(3-4): 75-84. http://dx.doi. org/10.1017/S0022149X00031655.

Collomb J, Machouart M, Biava MF, Brizion M, Montagne K, Plénat F, et al. Contribution of NADH dehydrogenase subunit I and cytochrome C oxidase subunit I sequences toward identifying a case of human coenuriasis in France. J Parasitol 2007; 93(4): 934-937. http://dx.doi. org/10.1645/GE-1160R.1. PMid:17918379.

Culling CFA. Handbook of histopathological and histochemical techniques: including museum techniques. 3rd ed. London: Butterworth-Heinemann; 1974 .

Deressa A, Tilahun T, Tadesse A, Beyene M, Gebrewold G, Pal M. Assessment of Coenurus cerebralis and its economic impact in sheep brain harvested at Ethiopian Health and Nutrition Research Institute, Ethiopia. Int J Livest Res 2012; 2(2): 217-226.

Edwards G, Herbert I. Observations on the course of Taenia multiceps infections in sheep: clinical signs and post-mortem findings. Br Vet J1982; 138(6): 489-500. http://dx.doi.org/10.1016/S0007-1935(17)30934-X. PMid:7150943.

El Sinnary K, Tageldin M, Al Sumry H. Outbreak of coenurosis (Taenia species) in Anglonubian goats in the Sultanate of Oman. Vet Rec 1999; 144(11): 296-297. http://dx.doi.org/10.1136/vr.144.11.296. PMid:10204227.

Engbaek K, Johansen KS, Jensen ME. A new technique for Gram staining paraffin-embedded tissue. J Clin Pathol 1979; 32(2): 187-190. http:// dx.doi.org/10.1136/jcp.32.2.187. PMid:86548.

Epstein E, Proctor N, Heinz H. Intra-ocular Coenurus infestation. S Afr Med J 1959; 33: 602-604. PMid:13820487.

Gazioglu A, Simsek S, Kizil O, Ceribasi AO, Kesik HK, Ahmed H. Clinical, pathological and molecular evaluations and CT scan screening of coenurosis (Coenurus cerebralis) in sheep and calves. Rev Bras Parasitol Vet 2017; 26(1): 3-9. http://dx.doi.org/10.1590/s1984-29612016090. PMid:28177040.

Giadinis N, Brellou G, Pourliotis K, Papazahariadou M, Sofianidis G, Poutahidis T, et al. Coenurosis in a beef cattle herd in Greece. Vet Rec 2007; 161(20): 697-698. http://dx.doi.org/10.1136/vr.161.20.697. PMid:18024927.

Giadinis N, Panousis N, Karatzias H, Papazahariadou M, Polizopoulou Z. Cerebellar dysfunction in a calf with chronic coenurosis. Vet Rec 2009; 164(16): 505-506. http://dx.doi.org/10.1136/vr.164.16.505. PMid:19377093.

Gicik Y, Kara M, Arslan MO. Prevalence of Coenurus cerebralis in sheep in Kars Province, Turkey. Bull Vet Inst Pulawy 2007; 51(3): 379-382.

Haitchi G, Buchroithner J, Sonnberger M, Weis S, Fellner FA. AIRP best cases in radiologic-pathologic correlation: human coenurosis (Taenia
Larva). Radiographics 2012; 32(2): 517-521. http://dx.doi.org/10.1148/ rg.322105230. PMid:22411946.

Haridy M, Sakai H, El-Nahass E, El-Morsey A, Anwar S, Yanai T. Coenurus cerebralis cysts in the left lateral cerebral ventricle of a ewe. J Vet Med Sci 2013; 75(12): 1643-1646. http://dx.doi.org/10.1292/ jvms.13-0276. PMid:23884082.

Ing MB, Schantz PM, Turner JA. Human coenurosis in North America: case reports and review. Clin Infect Dis 1998; 27(3): 519-523. http:// dx.doi.org/10.1086/514716. PMid:9770151.

Karim M. A survey of coenurosis in sheep in Northern Iraq. Trop Anim Health Prod 1979; 11(3): 157-158. http://dx.doi.org/10.1007/ BF02237792. PMid:505588.

Kennedy MJ. Basic methods of specimen preparation in parasitology. Geneva: WHO; 1979. (Manuscript reports; vol. 8).

Kheirandish R, Sami M, Azizi S, Mirzaei M. Prevalence, predilection sites and pathological findings of Taenia multiceps coenuri in slaughtered goats from south-east Iran. Onderstepoort J Vet Res 2012; 79(1): 1-5. http:// dx.doi.org/10.4102/ojvr.v79i1.436. PMid:23327321.

Kwarteng AY, Dorvlo AS, Vijaya Kumar GT. Analysis of a 27-year rainfall data (1977-2003) in the Sultanate of Oman. Int J Climatol 2009; 29(4): 605-617. http://dx.doi.org/10.1002/joc. 1727.

Lescano AG, Zunt J. Other cestodes: sparganosis, coenurosis and Taenia crassiceps cysticercosis. Handb Clinl Neurol 2013; 114: 335-345. https:// dx.doi.org/10.1016\%2FB978-0-444-53490-3.00027-3.

Loos-Frank B. An up-date of Verster's (1969) 'Taxonomic revision of the genus Taenia Linnaeus' (Cestoda) in table format. Syst Parasitol 2000; 45(3): 155-184. http://dx.doi.org/10.1023/A:1006219625792. PMid:10768761.

Mascate. Ministry of Agriculture and Fisheries - MAF. Oman agricultural census [online]. Mascate: Ministry of Agriculture and Fisheries, Muscat, Oman; 2013 [cited 2018 December 3]. Available from: https://www. oman.om/wps/wcm/connect/EN/site/home/gov/gov3/asd/

Michal A, Regli F, Campiche R, Cavallo R, Crousaz G, Oberson R, et al. Cerebral coenurosis. J Neurol 1977; 216(4): 265-272. http://dx.doi. org/10.1007/BF00314050. PMid:72809.

Moghaddar N. Coenurosis in sheep of fars province, Iran. J Appl Anim Res 2007; 31(1): 65-67. http://dx.doi.org/10.1080/09712119.2007.9706631.

Nourani H, Kheirabadi KP. Cerebral coenurosis in a goat: pathological findings and literature review. Comp Clin Pathol 2009; 18(1): 85-87. http://dx.doi.org/10.1007/s00580-008-0742-2.

Oge H, Oge S, Gonenc B, Ozbakis G, Asti C. Coenurosis in the lumbar region of a goat: a case report. Vet Med (Praha) 2012; 57(6): 308-313. http://dx.doi.org/10.17221/6018-VETMED.

Oryan A, Akbari M, Moazeni M, Amrabadi O. Cerebral and noncerebral coenurosis in small ruminants. Trop Biomed 2014; 31(1): 1-16. PMid:24862039.

Oryan A, Moazeni M, Amrabadi O, Akbari M, Sharifiyazdi H. Comparison of distribution pattern, pathogenesis and molecular characteristics of larval stages of Taenia multiceps in sheep and goats. Small Rum Res 2015; 132: 44-49.

Polizopoulou SZ, Giadinis DN, Papahristou A, Papaioannou N. Neurological diseases of small ruminants in greece: a retrospective study in 114 flocks. Acta Vet 2016; 66(2): 160-171. https://doi.org/10.1515/ acve-2016-0014. 
Razig SA, Magzoub M. Goat infected with Coenurus cerebralis--clinical manifestations. Trop Anim Health Prod 1973; 5(4): 278-280. http:// dx.doi.org/10.1007/BF02240429. PMid:4802487.

Rostami S, Beech RN, Salavati R, Baneshi MR, Kamyabi H, Harandi MF. Morphometric analysis of larval rostellar hooks in Taenia multiceps of sheep in Iran and its association with mitochondrial gene variability. Iran J Parasitol 2013; 8(4): 579-585. PMid:25516739.

Sami M, Mirzaei M, Kheirandish R. Intramuscular and subcutaneous coenurosis in goats and sheep in south-east Iran. Comp Clin Pathol 2014; 23(1): 141-144. http://dx.doi.org/10.1007/s00580-012-1585-4.

Scala A, Varcasia A. Updates on morphobiology, epidemiology and molecular characterization of coenurosis in sheep. Parassitologia 2006; 48(1-2): 61-63. PMid:16881398.

Schellhas KP, Norris GA. Disseminated human subarachnoid coenurosis: computed tomographic appearance. AJNR Am J Neuroradiol 1985; 6(4): 638-640. PMid:3927683.

Schuster RK, Sivakumar S, Wieckowsky T. Non-cerebral coenurosis in goats. Parasitol Res 2010; 107(3): 721-726. http://dx.doi.org/10.1007/ s00436-010-1919-6. PMid:20502917.

Sharma D, Chauhan P. Coenurosis status in Afro-Asian region: a review. Small Rumin Res 2006; 64(3): 197-202. http://dx.doi.org/10.1016/j. smallrumres.2005.05.021.
Shivasharanappa N, Sharma N, Sharma DK, Pawaiya RS, Vamadevan B, Mishra AK, et al. Neuropathological lesions of clinical and sub clinical Coenurosis (Coenurus cerebralis) in organized goat farms in India. Acta Parasitol 2017; 62(2): 482-487. http://dx.doi.org/10.1515/ap-20170057. PMid:28426417.

Soulsby EJL. Helminths, arthropods and protozoa of domesticated animals. Kent: Bailliere Tindall; 1982.

Tavassoli M, Malekifard F, Soleimanzadeh A, Tajik H. Prevalence of Coenurus cerebralis in sheep in Northwest of Iran. Vet Res Forum 2011; 2(4): 274-276.

Tirgari M, Howard B, Boargob A. Clinical and radiographical diagnosis of coenurosis cerebralis in sheep and its surgical treatment. Vet Rec 1987; 120(8A): 173-178. http://dx.doi.org/10.1136/vr.120.8a.173. PMid:3564308.

van der Zanden A, Hoentjen A, Heilmann F, Weltevreden E, Schouls L, van Embden J. Simultaneous detection and strain differentiation of Mycobacterium tuberculosis complex in paraffin wax embedded tissues and in stained microscopic preparations. Mol Pathol 1998; 51(4): 209-214. http://dx.doi.org/10.1136/mp.51.4.209. PMid:9893747.

Verster A. A taxonomic revision of the genus Taenia Linnaeus, 1758, s. str. Onderstepoort J Vet Res 1969; 36(1): 3-58. PMid:5407584. 